\title{
Occlusions in peripherally inserted central venous catheters in pediatric patients in antineoplastic chemotherapy
}

\author{
Oclusões em cateteres venosos centrais de inserção periférica nos \\ pacientes infantojuvenis em quimioterapia antineoplásica \\ Oclusiones en catéteres centrales de inserción periférica en niños \\ y adolescentes en quimioterapia antineoplásica
}

\author{
Bruna Irene Cunha Curty de Souza ${ }^{a}$ (i) \\ Marcelle Miranda da Silva ${ }^{a}$
}

\section{How to cite this article:} Souza BICC, Silva MM. Occlusions in peripherally inserted central venous catheters in pediatric patients in antineoplastic chemotherapy. Rev Gaúcha Enferm. 2021;42:e20190495. doi: https://doi. org/10.1590/1983-1447.2021.20190495 aniversidade Federal do Rio de Janeiro (UFRJ), Escola de Enfermagem Anna Nery, Programa de Pós-Graduação Stricto Sensu. Rio de Janeiro, Rio de Janeiro, Brasil.

\section{ABSTRACT}

Objective: To analyze the occurrence of occlusions in peripherally inserted central venous catheters in pediatric patients in antineoplastic chemotherapy.

Method: Retrospective cohort, with 156 medical records of patients aged 0-19 years who underwent outpatient chemotherapy between 2013 and 2017 by this catheter, in a hospital in the city of Rio de Janeiro. Descriptive and inferential statistics were applied. Results: 219 catheters were registered. Occlusion occurred in 141 (64.4\%) catheters; 63 (44.7\%) were removed because of occlusion, either alone or associated with another factor. Total occlusion alone led to the removal of 27 (12.3\%) catheters. Occlusion was associated with: catheter dwell time, cyclophosphamide, neuroblastoma, bone metastasis and number of chemotherapy sessions. Conclusion: Occlusion is an important complication because it occurred in more than half of the catheters and was one of the main reasons for withdrawal. The identified risk factors may guide the care to prevent this complication.

Keywords: Central venous catheters. Vascular access devices. Catheter obstruction. Neoplasms. Pediatrics.

\section{RESUMO}

Objetivo: Analisar a ocorrência de oclusões em cateteres venosos centrais de inserção periférica nos pacientes infantojuvenis em quimioterapia antineoplásica.

Método: Coorte retrospectivo, com 156 prontuários de pacientes de 0 a 19 anos que realizaram quimioterapia ambulatorialmente entre 2013 e 2017 por este cateter, em hospital do município do Rio de Janeiro. Aplicou-se estatística descritiva e inferencial.

Resultados: Registraram-se 219 cateteres. A oclusão ocorreu em 141 (64,4\%) cateteres; 63 (44,7\%) foram retirados por causa da oclusão, seja isolada ou associada a outro fator. A oclusão total isoladamente foi motivo de retirada de 27 (12,3\%) cateteres. A oclusão apresentou associação com: tempo de permanência do cateter, ciclofosfamida, neuroblastoma, metástase óssea e número de sessões de quimioterapia.

Conclusão: A oclusão é uma complicação importante, pois ocorreu em mais da metade dos cateteres e foi um dos principais motivos de retirada. Os fatores de risco identificados podem nortear o cuidado para prevenção desta complicação.

Palavras-chave: Cateteres venosos centrais. Dispositivos de acesso vascular. Obstrução do cateter. Neoplasias. Pediatria.

\section{RESUMEN}

Objetivo: Analizar la aparición de oclusiones en catéteres centrales de inserción periférica en niños y adolescentes sometidos a quimioterapia.

Método: Cohorte retrospectiva, con 156 registros de pacientes de 0 a 19 años que se sometieron a quimioterapia entre 2013 y 2017 , en un hospital de Río de Janeiro. Se aplicaron estadísticas descriptivas e inferenciales.

Resultados: Se registraron 219 catéteres. La oclusión ocurrió en 141 (64.4\%) catéteres; 63 (44.7\%) se eliminaron por oclusión, ya sea solo 0 asociado con otro factor. La oclusión total sola condujo a la extracción de 27 (12.3\%) catéteres. La oclusión se asoció con la duración de la estancia del catéter, ciclofosfamida, neuroblastoma, metástasis óseas y sesiones de quimioterapia.

Conclusión: La oclusión es una complicación importante, ocurrió en más de la mitad de los catéteres y fue una de las principales razones para la retirada. Los factores de riesgo pueden guiar la atención para prevenir esta complicación.

Palabras clave: Catéteres venosos centrales. Dispositivo de acceso vascular. Obstrucción del catéter. Neoplasias. Pediatría. 


\section{INTRODUCTION}

In Brazil and worldwide, cancer represents the main cause of death from illness among children and adolescents, but it has achieved high cure rates ${ }^{(1-2)}$. Anticancer treatments are complex and involve the use of three basic modalities: surgery, chemotherapy, and radiotherapy. In general, they are long and aggressive, and often need secure access to the venous network to administer, for example, chemotherapeutics ${ }^{(3)}$

Chemotherapy contributes to increased survival, since childhood cancers have a high proliferative index and are mostly chemosensitive ${ }^{(2)}$. The main route of administration of chemotherapy drugs is intravenous, with vascular catheterization being one of the most performed procedures ${ }^{(4-5)}$. In view of the risk of drug leakage, the need to optimize treatment and promote comfort, it is necessary to ensure safe and long-term venous access, such as through the central venous catheter ${ }^{(6)}$.

The present study addresses the use of the Peripherally Inserted Central Venous Catheter (PICC), as it is widely used in pediatric oncology for providing comfort and safety; having the final location of its tip in a central vein; be long-term; dispense the use of the operating room, being able to be inserted in a variety of clinical settings, with a high rate of success in insertion, by a trained professional, such as the nurse; and have a better cost and benefit ratio compared to other central venous catheters ${ }^{(5-7)}$.

Despite the advantages, the use of PICC can be related to complications, especially infections and occlusions, which, by themselves, due to their consequences, or the need to interrupt treatment, can threaten the lives of children and adolescents, increase the period of hospitalization, worsen the quality of life, generate higher costs with assistance, and greater workload for the health team ${ }^{(6-8)}$.

A study that categorized the occurrence of notifications of adverse events and technical complaints related to the use of vascular catheters, received by the notification system of the National Health Surveillance Agency (Agência Nacional de Vigilância Sanitária - ANVISA), in the period between January 2007 and June 2016, showed that the PICC occupied the second position, with 1132 (21\%) notifications; it was responsible for three deaths, out of a total of four; and of 671 notifications of adverse events, it was responsible for $269(40 \%)^{(4)}$.

The highest occurrence of complications in PICC occurs, especially, in pediatric oncology/hematology. The occurrence of occlusion was highlighted as one of the central themes most investigated in scientific productions, however there is a knowledge gap in the relationship between the clinical and pathological profile of the clientele with this complication ${ }^{(4-8)}$.
Although the permeability of the PICC can be restored in many situations, occlusion is one of the main reasons for its early withdrawa $\left.\right|^{(8)}$. Thus, the question arises: does the clinical-pathological profile of pediatric patients in antineoplastic chemotherapy treatment interfere with the occurrence of occlusions in PICC?

The objective was to analyze the occurrence of occlusions in PICC in pediatric patients in antineoplastic chemotherapy.

\section{METHOD}

Retrospective cohort study, carried out between June and November 2018, in a public institution specialized in cancer, located in Rio de Janeiro, with a pediatric oncology service, assisting children and adolescents with various types of cancer.

Inclusion criteria were: medical records of patients enrolled in the institution, with attendance records in the pediatric oncology session between 2013 and 2017, from 0 to 19 years of age, of both genders, who underwent chemotherapy treatment at the outpatient clinic, through PICC, with or without complications. The occurrence of occlusion was analyzed from the insertion of the first catheter, until its removal or death of the patient.

The stratification of the age group followed the guidelines of the International Agency for Research on Cancer, which, in collaboration with the International Association of Cancer Registries, developed a combination of age structures in developed or developing countries, standardizing the following classification: less than 1 year, from 1 to 4 years, 5 to 9 years, 10 to 14 years, and 15 to 19 years ${ }^{(2)}$.

It was identified 194 medical records of patients who used the PICC in the investigated period, of which 156 were included in the study. In these,219 PICC were identified, since some patients had more than one PICC during treatment.

Exclusion criteria were: medical records of patients with previous coagulopathy; with incomplete or missing information; of patients who have not removed the PICC at the time of data collection; of patients who underwent chemotherapy hospitalized, since the PICC would be in continuous infusion of solution, presenting a profile of care and routines different from the use of PICC during outpatient chemotherapy treatment.

38 medical records were excluded: ten patients underwent chemotherapy hospitalized, nine patients had not removed the PICC, seven did not undergo chemotherapy by the PICC, four had incomplete information, another four had been sent to another hospital unit, three medical records were not found; and one patient had coagulopathy.

For data collection, it was used a form elaborated by the researchers with the variables: gender, age, type of cancer, 
presence and location of metastasis, complementary treatments, chemotherapeutics used, dwell time, place of insertion and type of PICC, occurrence and type of occlusion, performance and interval between maintenance for catheter permeability, presence and type of previous catheter, and reason for withdrawing the PICC.

The data were processed in the Statistical Package for the Social Sciences (SPSS), version 22.0. The descriptive statistical analysis was performed using the Chi-square test, Student's t-test, Mann-Whitney, and Odds Ratio (OR) calculations as a measure of association. When Chi-square proved inconclusive, Fisher's exact test was used.

The discussions were held considering the maximum significance level of $5 \%(0.05)$, that is, the following decision rule was adopted in the tests: rejection of the null hypothesis whenever the $p$-value associated with the test was less than 0.05. In the tests that provided the asymptotic and exact $p$-values, the exact $p$-values were considered.

The project was approved by the Research Ethics Committee in April 2018 (Statement No.2,608,161). Waiver of the informed consent form was requested.

\section{Q RESULTS}

From 156 patients, 70 (44.9\%) were female and 86 (55.1\%) were male. The distribution in the age groups was presented as follows: 55 (35.3\%) patients aged 10 to 14 years, 54 (34.6\%) patients aged 15 to 19 years, 28 (17.9\%) patients aged 5 at 9 years, 16 (10.3\%) patients from 1 to 4 years, and $3(1.9 \%)$ patients under 1 year. The average age was 11.8 years, with a median of 13 and a variation coefficient of 0.4 , which showed moderate variability between ages. However, the Mann-Whitney test, with a p-value of 0.461 , found that there was no significant difference between ages in different genders.

Due to the characteristics of the institution, considering the oncology care network, it was evident that solid tumors were the most prevalent, affecting 140 (89.7\%) patients, with osteosarcoma being the most frequent diagnosis in the 15 to 19 year old age group and Wilms tumor in children younger than 1 year (Table 1). Bone tumors were more frequent, with 47 (30.1\%) cases, soft tissue sarcomas with 33 (21.2\%) cases, and tumors of the Central Nervous System (CNS) and miscellaneous intracranial and intraspinal neoplasms, with $23(14.7 \%)$ cases.

From the characteristics of chemotherapy treatment, 69 (44.2\%) patients underwent 1 to 6 chemotherapy sessions by PICC; 52 (33.4\%) performed from seven to 12 sessions; $17(11 \%)$ performed 13 to 18 sessions; while ten (6.5\%) performed 19 to 24 sessions. There were few occurrences over 25 sessions; four (2.5\%) performed 25 to 30 sessions; two (1.2\%) performed 43 to 48 sessions; and two others (1.2\%) from 49 to
55 sessions. The average number of chemotherapy sessions was 9.7, with a median of 8 sessions, standard deviation of 8.8 with a variation coefficient of 0.9 , showing high variability between the number of sessions. The Mann-Whitney test ( $p$-value $=0.332$ ) found that there was no significant difference between the number of chemotherapy sessions performed by patients of different genders.

The number of chemotherapeutic agents in each protocol varied from 1 to $6: 54$ (34.6\%) patients used three chemotherapeutic agents; 44 (28.2\%) used two chemotherapeutic agents; 23 (14.7\%) used four; 16 (10.3\%) used five; 15 (9.6\%) used one; and only four (2.6\%) patients used six chemotherapeutic agents. On average, three chemotherapeutic agents were used in combination, with a standard deviation of 1.2 and a coefficient of variation of 0.41 . The Mann-Whitney test ( $p$-value $=0.648$ ) found that there was no significant difference between the number of antineoplastic chemotherapeutic agents used by each patient of different genders.

From the chemical structure of chemotherapeutic agents it was identified, 129 (82.7\%) alkylating agents, 102 (65.4\%) antitumor antibiotics, 101 (64.7\%) alkaloid plants, 47 (30.1\%) antimetabolic agents, and two (1.3\%) monoclonal antibodies. When considering cytotoxicity, 128 (82.1\%) were vesicant, 125 (80.1\%) were irritating, and 81 (51.9\%) non-vesicant.

Most patients, that is, 107 (68.6\%), had at least one complementary treatment to chemotherapy; and metastasis occurred in 47 (30.1\%) patients. Considering the type of metastasis, it was observed that the most frequent were in the lung in 31 (19.9\%) patients, and in the bone marrow in 10 (6.4\%) patients (Table 2). In cases of metastasis, 33 (70.2\%) patients had metastasis to only one location; 12 (25.5\%) patients had metastases in two locations, and another two (4.3\%) patients had metastases in three locations.

During the treatment with chemotherapy,219 PICC were inserted in the 156 patients, distributed as follows: 112 (71.8\%) patients had only one PICC; 31 (19.9\%) patients had two PICC; nine (5.8\%) patients had three PICC; two (1.3\%) patients had four PICC and two (1.3\%) patients had five PICC. All 219 PICCS were made of silicone. PICC was the catheter of first choice in 151 (96.8\%) patients; three (1.9\%) catheters previous to PICC were fully implanted central venous catheters, and two (1.3\%) were semi-implanted central venous catheters.

From the interval between permeability maintenance, seven days prevailed in 119 (54.3\%) PICC; followed by an interval of eight to 14 days in 50 (22.8\%) PICC; interval between chemotherapy sessions less than seven days in 43 (19.6\%) PICC; and interval greater than 14 days in five (2.3\%) PICC. In two $(0.9 \%)$ PICC this variable was not identified.

In the 63 cases of new PICC insertions, in 27 (42.9\%) there was no change in the vein; in 19 (30.2\%) cases it was changed from brachial to basilica; in 11 (17.5\%) cases it was changed 
Table 1 - Types of global cancer and by age group. Rio de Janeiro, RJ, Brazil, 2013-2017 (n=156)

\begin{tabular}{|c|c|c|c|c|c|c|c|c|c|c|c|c|}
\hline \multirow[t]{2}{*}{ Diagnosis } & \multicolumn{2}{|c|}{$\begin{array}{l}\text { Global } \\
n=156\end{array}$} & \multicolumn{2}{|c|}{$\begin{array}{c}\text { Under } 1 \\
\begin{array}{c}\text { year } \\
\mathbf{n}=\mathbf{3}\end{array}\end{array}$} & \multicolumn{2}{|c|}{$\begin{array}{c}1-4 \\
\text { years } \\
n=16\end{array}$} & \multicolumn{2}{|c|}{$\begin{array}{c}5-9 \\
\text { years } \\
n=28\end{array}$} & \multicolumn{2}{|c|}{$\begin{array}{l}10-14 \\
\text { years } \\
n=55\end{array}$} & \multicolumn{2}{|c|}{$\begin{array}{l}15-19 \\
\text { years } \\
n=54\end{array}$} \\
\hline & $\mathbf{F}$ & $\%$ & $\mathbf{F}$ & $\%$ & $\mathbf{F}$ & $\%$ & $\mathbf{F}$ & $\%$ & $\mathbf{F}$ & $\%$ & $\mathbf{F}$ & $\%$ \\
\hline Osteosarcoma & 43 & $27.6 \%$ & 0 & $0.0 \%$ & 0 & $0.0 \%$ & 4 & $14.3 \%$ & 17 & $30.9 \%$ & 22 & $40.7 \%$ \\
\hline Wilms Tumor & 13 & $8.3 \%$ & 1 & $33.3 \%$ & 5 & $31.2 \%$ & 6 & $21.4 \%$ & 1 & $1.8 \%$ & 0 & $0.0 \%$ \\
\hline Rhabdomyosarcoma & 12 & $7.7 \%$ & 0 & $0.0 \%$ & 0 & $0.0 \%$ & 2 & $7.1 \%$ & 4 & $7.4 \%$ & 6 & $11.0 \%$ \\
\hline Hodgkin Lymphoma & 10 & $6.4 \%$ & 2 & $66.7 \%$ & 0 & $0.0 \%$ & 0 & $0.0 \%$ & 2 & $3.6 \%$ & 6 & $11.0 \%$ \\
\hline $\mathrm{PNET}^{*}$ & 10 & $6.4 \%$ & 0 & $0.0 \%$ & 0 & $0.0 \%$ & 2 & $7.1 \%$ & 6 & $11.0 \%$ & 2 & $3.7 \%$ \\
\hline Medulloblastoma & 8 & $5.1 \%$ & 0 & $0.0 \%$ & 2 & $12.5 \%$ & 2 & $7.1 \%$ & 1 & $1.8 \%$ & 3 & $5.6 \%$ \\
\hline Neuroblastoma & 7 & $4.5 \%$ & 0 & $0.0 \%$ & 5 & $31.3 \%$ & 1 & $3.6 \%$ & 1 & $1.8 \%$ & 0 & $0.0 \%$ \\
\hline Sarcoma & 5 & $3.1 \%$ & 0 & $0.0 \%$ & 0 & $0.0 \%$ & 2 & $7.1 \%$ & 2 & $3.6 \%$ & 1 & $1.9 \%$ \\
\hline $\begin{array}{l}\text { Nasopharyngeal } \\
\text { Carcinoma }\end{array}$ & 4 & $2.6 \%$ & 0 & $0.0 \%$ & 0 & $0.0 \%$ & 0 & $0.0 \%$ & 2 & $3.6 \%$ & 2 & $3.7 \%$ \\
\hline Ewing Sarcoma & 3 & $1.9 \%$ & 0 & $0.0 \%$ & 0 & $0.0 \%$ & 0 & $0.0 \%$ & 1 & $1.8 \%$ & 2 & $3.7 \%$ \\
\hline Germinoma & 2 & $1.3 \%$ & 0 & $0.0 \%$ & 0 & $0.0 \%$ & 0 & $0.0 \%$ & 1 & $1.8 \%$ & 1 & $1.9 \%$ \\
\hline $\begin{array}{l}\text { Acute Lymphoid } \\
\text { Leukemia }\end{array}$ & 2 & $1.3 \%$ & 0 & $0.0 \%$ & 0 & $0.0 \%$ & 0 & $0.0 \%$ & 1 & $1.8 \%$ & 1 & $1.9 \%$ \\
\hline $\begin{array}{l}\text { T- Lymphoblastic } \\
\text { lymphoma }\end{array}$ & 2 & $1.3 \%$ & 0 & $0.0 \%$ & 0 & $0.0 \%$ & 2 & $7.1 \%$ & 0 & $0.0 \%$ & 0 & $0.0 \%$ \\
\hline Pineoblastoma & 2 & $1.3 \%$ & 0 & $0.0 \%$ & 0 & $0.0 \%$ & 1 & $3.6 \%$ & 0 & $0.0 \%$ & 1 & $1.9 \%$ \\
\hline Synoviosarcoma & 2 & $1.3 \%$ & 0 & $0.0 \%$ & 0 & $0.0 \%$ & 0 & $0.0 \%$ & 0 & $0.0 \%$ & 2 & $3.7 \%$ \\
\hline Immature Teratoma & 2 & $1.3 \%$ & 0 & $0.0 \%$ & 0 & $0.0 \%$ & 0 & $0.0 \%$ & 2 & $3.6 \%$ & 0 & $0.0 \%$ \\
\hline $\begin{array}{l}\text { Endodermal } \\
\text { Sinus Tumor }\end{array}$ & 2 & $1.3 \%$ & 0 & $0.0 \%$ & 0 & $0.0 \%$ & 1 & $3.6 \%$ & 1 & $1.8 \%$ & 0 & $0.0 \%$ \\
\hline Others & 27 & $17.3 \%$ & 0 & $0.0 \%$ & 4 & $25.0 \%$ & 5 & $17.8 \%$ & 13 & $23.7 \%$ & 5 & $9.3 \%$ \\
\hline
\end{tabular}

Source: Research data, 2013-2017.

* Primitive Neuroectodermal Tumor

from the basilica to the cephalic; in three (4.7\%) cases it was changed from brachial to cephalic. In three (4.7\%) of cases, this variable was not identified. The right upper limb was the most chosen for the insertion of the PICC, with 171 (78.1\%) cases. And the basilic vein was chosen in 132 (60.3\%) cases; followed by 51 (23.3\%) cases in the brachial vein and 26
(11.8\%) cases in the cephalic vein. In 10 (4.6\%) records this variable was not found.

The average dwell time of the PICC, without outliers, was 128.9 days (approximately 4.3 months) and the median was 118 days (approximately four months). Were outliers the five (2.3\%) PICC that lasted more than 400 days; and aberrant 
Table 2 - Frequency distributions of metastasis, complementary treatment and death, global and by gender, RJ, Brazil, 2013-2017 (n=156)

\begin{tabular}{|c|c|c|c|c|c|c|c|}
\hline \multirow[t]{2}{*}{ Variables } & \multicolumn{2}{|c|}{$\begin{array}{l}\text { Global } \\
n=156\end{array}$} & \multicolumn{2}{|c|}{$\begin{array}{c}\text { Female } \\
n=70\end{array}$} & \multicolumn{2}{|c|}{$\begin{array}{l}\text { Male } \\
\mathrm{n}=\mathbf{8 6}\end{array}$} & \multirow{2}{*}{$\begin{array}{l}\text { p-value of the } \\
\text { Chi-square test } \\
\text { (by gender) }\end{array}$} \\
\hline & $\mathbf{F}$ & $\%$ & $\mathbf{F}$ & $\%$ & $\mathbf{F}$ & $\%$ & \\
\hline Metastasis & 47 & $30.1 \%$ & 22 & $31.4 \%$ & 25 & $29.1 \%$ & 0.749 \\
\hline Pulmonary & 31 & $19.9 \%$ & 15 & $21.4 \%$ & 16 & $18.6 \%$ & 0.365 \\
\hline Bone Marrow & 10 & $6.4 \%$ & 3 & $4.3 \%$ & 7 & $8.1 \%$ & $0.513^{*}$ \\
\hline Bone & 9 & $5.8 \%$ & 3 & $4.3 \%$ & 6 & $7.0 \%$ & 0.473 \\
\hline Hepatic & 5 & $3.2 \%$ & 1 & $1.4 \%$ & 4 & $4.7 \%$ & $0.380^{*}$ \\
\hline CNS & 1 & $0.6 \%$ & 0 & $0.0 \%$ & 1 & $1.2 \%$ & $1.00^{*}$ \\
\hline Abdominal & 1 & $0.6 \%$ & 1 & $1.4 \%$ & 0 & $0.0 \%$ & $0.449^{*}$ \\
\hline Leptomeningeal spread & 2 & $1.3 \%$ & 0 & $0.0 \%$ & 2 & $2.3 \%$ & $0.502^{*}$ \\
\hline Lymph Node & 2 & $1.3 \%$ & 2 & $2.9 \%$ & 0 & $0.0 \%$ & $0.200^{*}$ \\
\hline Omentum & 1 & $0.6 \%$ & 1 & $1.4 \%$ & 0 & $0.0 \%$ & $0.449^{*}$ \\
\hline Pleural fluid & 1 & $0.6 \%$ & 0 & $0.0 \%$ & 1 & $1.2 \%$ & $1.000^{*}$ \\
\hline \multicolumn{8}{|l|}{ Complementary Treatment } \\
\hline None & 49 & $31.4 \%$ & 24 & $34.3 \%$ & 25 & $29.1 \%$ & 0.235 \\
\hline Surgery & 91 & $58.3 \%$ & 45 & $64.3 \%$ & 46 & $53.5 \%$ & 0.174 \\
\hline Radiotherapy & 47 & $30.1 \%$ & 20 & $28.6 \%$ & 27 & $31.4 \%$ & 0.702 \\
\hline Surgery and Radiotherapy & 31 & $19.9 \%$ & 19 & $27.1 \%$ & 12 & $14.0 \%$ & 0.046 \\
\hline Surgery Only & 60 & $38.5 \%$ & 26 & $37.1 \%$ & 34 & $39.5 \%$ & 0.869 \\
\hline Radiotherapy Only & 16 & $10.3 \%$ & 1 & $1.4 \%$ & 15 & $17.4 \%$ & 0.001 \\
\hline Death & 46 & $29.5 \%$ & 18 & $25.7 \%$ & 28 & $32.6 \%$ & 0.351 \\
\hline
\end{tabular}

Source: Research data, 2013-2017.

* In these comparisons it was used the Fisher's exact test.

outliers the 11 (5.0\%) PICC that lasted more than 600 days. The coefficient of variation of 0.67 showed the high variability in the duration of the PICC, even without considering the outliers.141 PICC were recorded with occlusion of the 219 PICC evaluated, showing an incidence of $64.4 \%$ of occlusion. Total occlusion, alone or in combination with other factors, was the reason for withdrawing 60 (27.6\%) PICC.
Partial occlusion in combination with exteriorization was responsible for removing three (1.3\%) PICC (Figure 1).

Total occlusion was only identified in isolation as the reason for withdrawing 27 (12.3\%) PICC; in the other cases, it was in combination with one or more of the following factors: rupture, exteriorization, infection, accidental traction and extravasation.

From the 141 catheters that had occlusion, 63 (44.7\%) were removed because of the occlusion, either alone or 
in combination with other factors; the other 78 (55.3\%) PICC were not removed because of the occlusion, as their permeability was restored. There is no significant difference between these two proportions ( $p$-value $=0.178$ from the binomial test). There is no significant association between occlusion and catheter removal by occlusion.

The incidence of occlusion in the catheters in which the patients had neuroblastoma was significantly higher than the occlusion in the catheters when the case was not neuroblastoma. The occlusion occurred at a significantly higher frequency among the 12 cases of neuroblastoma (92.3\%, $\mathrm{p}$-value $=0.035$ ). The odds ratio $(\mathrm{OR})$ was 7.2 (confidence interval: 1.1 - 56.2). It is estimated that the chance of a catheter in a patient who has neuroblastoma to present occlusion is 7.2 times the chance of a catheter of a patient who does not have neuroblastoma to present occlusion (Table 3).

There was a significant association between occlusion and bone metastasis ( $p$-value $=0.035$ ). Occlusion occurred more frequently among the 12 (92.3\%) cases with bone metastasis. The OR was 7.2 (confidence interval: 1.1 - 56). It is estimated that the chance of a catheter in a patient who has bone metastasis to present occlusion is 7.2 times the chance of a catheter in a patient who does not have bone metastasis to present occlusion (Table 3).
The incidence of occlusion was associated with the use and non-use of medications. There was a significant association between occlusion and cyclophosphamide. Occlusion occurred significantly more frequently among the 36 (80.0\%) patients who used cyclophosphamide. The OR was equal to 2.6 (confidence interval: 1.2 - 5.8). It is estimated that the chance of a catheter in a patient using cyclophosphamide to present occlusion is 2.6 times greater than the chance of a catheter in a patient who does not use this medication to present occlusion (Table 3).

The significant association between bone metastasis and the concomitant use of cyclophosphamide is highlighted. Bone metastasis occurred in six (3.4\%) patients who did not use cyclophosphamide, and it occurred significantly more frequently among the seven (15.6\%) patients who used cyclophosphamide ( $p$-value 0.006 of Fisher's exact test). The OR was equal to 5.2 (confidence interval: 1.6 - 16.2). It is estimated that the chance of a patient using cyclophosphamide to have associated bone metastasis is 5.2 times greater than the chance of a patient not using this drug to have bone metastasis.

From the quantitative variables, the catheter occlusion was significantly associated with the number of chemotherapy sessions and the catheter dwell time (Table 4).

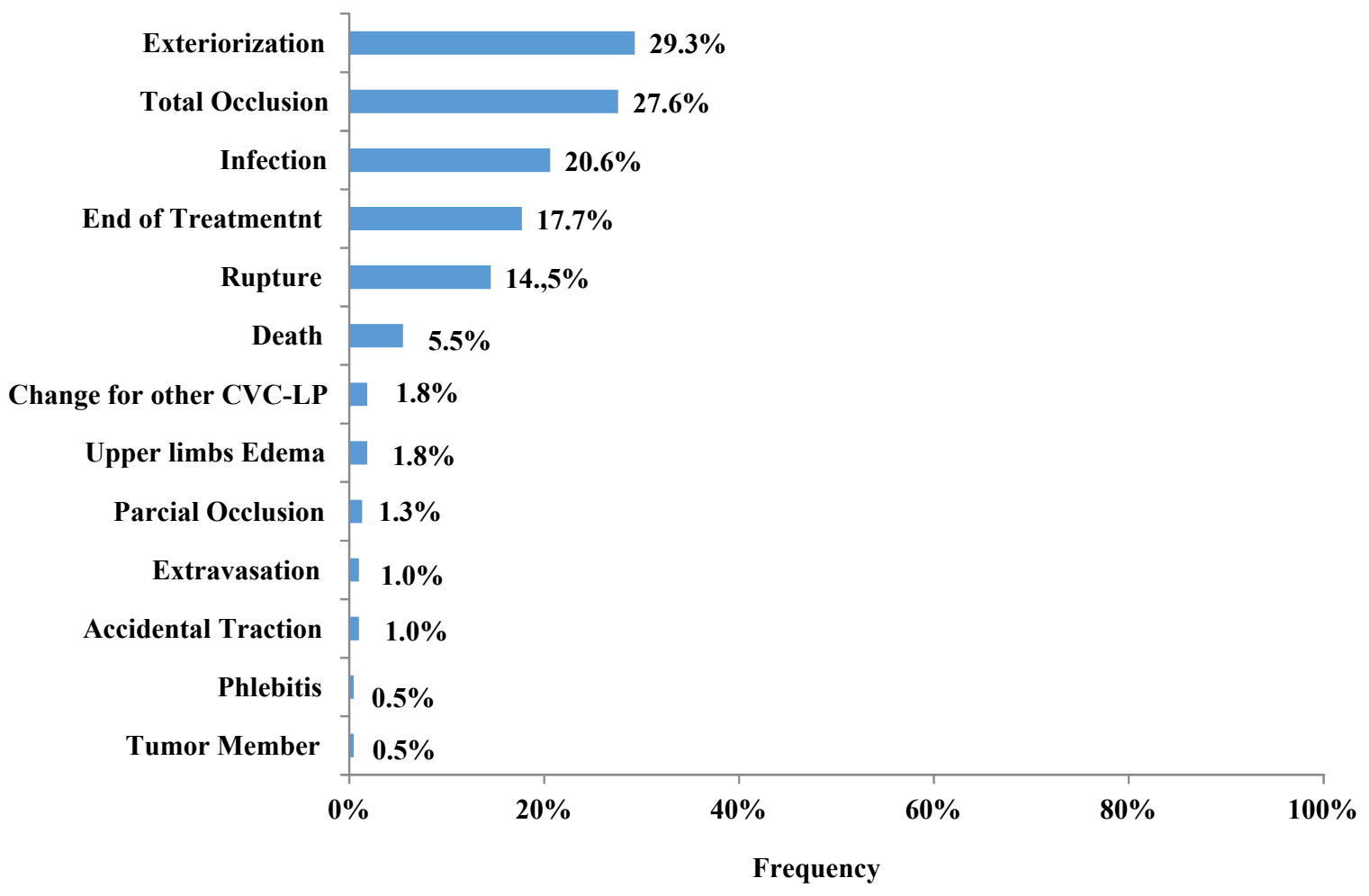

Figure 1 - Individual frequency of reasons for PICC removal. Rio de Janeiro, RJ, Brazil, 2013-2017 Source: Research data, 2013-2017. 
Table 3 - Factors associated with occlusion. Rio de Janeiro, RJ, Brazil, 2013-2017

\begin{tabular}{|c|c|c|c|c|c|}
\hline \multirow{2}{*}{ Factors } & \multicolumn{2}{|c|}{$\begin{array}{l}\text { Occlusion with the } \\
\text { missing factor }\end{array}$} & \multicolumn{2}{|c|}{$\begin{array}{l}\text { Occlusion with the } \\
\text { present factor }\end{array}$} & \multirow[t]{2}{*}{ p-value* } \\
\hline & $\mathbf{F}$ & $\%$ & $\mathbf{F}$ & $\%$ & \\
\hline Neuroblastoma & 129 & $62.6 \%$ & 12 & $92.3 \%$ & 0.035 \\
\hline Bone metastasis & 129 & $62.6 \%$ & 12 & $92.3 \%$ & 0.035 \\
\hline Medication Cyclophosphamide & 105 & $60.3 \%$ & 36 & $80.0 \%$ & $0.014^{(a)}$ \\
\hline
\end{tabular}

Source: research data, 2013-2017.

${ }^{*}$-value of Fisher's exact test comparing the incidence of occlusion in the two groups.

(a): in this case, the Chi-square test was used.

Table 4 - Quantitative variables associated with occlusion. Rio de Janeiro, 2013-2017

\begin{tabular}{|c|c|c|c|c|c|c|c|}
\hline \multirow{2}{*}{ Variable } & \multicolumn{3}{|c|}{ Without occlusion $(n=78)$} & \multicolumn{3}{|c|}{ With occlusion ( $n=141)$} & \multirow{2}{*}{$\begin{array}{l}\text { p-va- } \\
\text { lue* }\end{array}$} \\
\hline & Mean & Median & SD & Mean & Median & SD & \\
\hline $\begin{array}{l}\text { Number of } \\
\text { chemotherapy sessions }\end{array}$ & 7.7 & 6.0 & 7.6 & 10.9 & 8.0 & 8.7 & 0.000 \\
\hline PICC dwell time in days & 131.6 & 104.5 & 130.9 & 168.3 & 132.0 & 152.0 & 0.013 \\
\hline $\begin{array}{l}\text { PICC dwell time in days } \\
\text { (without outliers) }\end{array}$ & 107.3 & 100.5 & 74.55 & 140.9 & 125.0 & 89.92 & 0.009 \\
\hline
\end{tabular}

Source: research data, 2013-2017.

${ }^{*}$ p-value of the Mann-Whitney test. SD = standard deviation

Regarding the interval between permeability maintenance, no conclusions could be reached due to the small sample of the subgroup with an interval greater than 14 days. In the other variables, the differences were not statistically significant.

\section{DISCUSSION}

The sociodemographic characteristics of the participants in this study are in line with other studies in the area in which childhood cancers are slightly higher in male children (5,9-10). The average age of the patients at the time of the PICC insertion was 11.8 years, similarly to other studies that presented the averages: 11.2 years, 10.28 years and 9.7 years ${ }^{(10-12)}$. As it is a catheter that is externally exposed, it is assumed that older children have a greater understanding about the necessary care with the catheter ${ }^{(10)}$.
The predominant diagnosis was solid tumors, affecting $140(89.7 \%)$ patients. However, the literature shows that the most incident type of childhood cancer is leukemia (about $25 \%$ to $35 \%$ ). The difference in the proportion found reflects the organization of the oncology care network in the state of Rio de Janeiro, as there is another exclusive hematology institution, in addition to others that offer pediatric care. It is also noteworthy that the scenario of this study generally receives the rarest and least prevalent cancers ${ }^{(1)}$.

In the 10 to 19 age group, osteosarcoma was significantly more frequent, which is the peak incidence reported in the literature. No case of osteosarcoma was found in children under five; bone tumors rarely occur before this age. The cause of this type of tumor has so far not been identified, but hormonal changes typical of adolescence due to growth may be related to the development of osteosarcoma in this age group. Osteosarcoma accounts for 
3-5\% of all childhood and adolescent cancers, and is more common in boys ${ }^{(1,13)}$.

The data on the type of tumor, following the International Classification of Childhood Cancer (ICCC), showed that neoplasms in the age groups of 10 to 14 years and 15 to 19 years old fit mainly in group VIII - Malignant bone tumors ${ }^{(2,14)}$. And Wilms tumor was significantly more frequent in children, followed by neuroblastoma. Kidney tumors correspond to 5-10\% of childhood tumor cases. Among the types of kidney tumors that affect children, $95 \%$ of them are Wilms tumors ${ }^{(2)}$. At ICCC, neoplasms in children aged 0 to 5 years are more frequent in groups IV - Tumors of the Sympathetic Nervous System and $\mathrm{VI}$ - Renal Tumors.

In relation to the presence of metastasis, this occurred in 47 (30.1\%) patients, with pulmonary metastases (19.9\%) being more frequent, which are responsible for cancer lethality; $74.2 \%$ of patients who had pulmonary metastasis died in the period evaluated. This data is related to the most frequent type of tumor in the sample, since it is estimated that metastases occur in $20 \%$ of patients with osteosarcoma and appear normally in the lungs. Pulmonary micrometastases are common in diagnosis in most cases of osteosarcoma. This is a very aggressive type of cancer, especially when associated with pulmonary metastasis; the survival rate for patients with pulmonary metastasis after aggressive treatment is five years ${ }^{(13,15-16)}$

Regarding deaths, 46 patients (29.5\%) died in the investigated period, from these 18 (39.1\%) patients had osteosarcoma. In Brazil, cancer deaths among children, adolescents and young adults are the second leading cause of death from illness. In the period from 2009 to 2013, the average mortality rate, adjusted for age, was 32.07 per million in the 0 to 14 age group and 44.25 per million in the 0 to 19 age group ${ }^{(2,16)}$.

The PICC was the catheter of first choice in 151 (96.8\%) cases, which is related to advantages related to operational facilities and cost/benefit ${ }^{(10-11,17)}$. Considering that the date of insertion of the PICC was always close to the patient's enrollment in the institution, this catheter accelerates the start of treatment, not requiring a surgical center.

Regarding the PICC's dwell time, the results showed a great variation in the number of days. The average was 155.2 days, median 123 days, talking to studies that bring results such as: median 152 days; PICC dwell interval between 24 and 247 days; longer PICC dwell time of 1.3 years, with an average of 6.3 months; and a study with adults highlighted the average dwell time of 184 days $(5,12,15,18)$.

As for the PICC permeability maintenance interval, the results showed that this practice was performed every seven days in $54.3 \%$ of the cases, and between eight and 14 days in $22.8 \%$, in line with the literature, although still there is little evidence about the standardization of permeability maintenance, which should be determined by institutional protocols $s^{(11-12)}$. It is noteworthy that the institutional protocol of the study scenario recommends maintaining the PICC for seven to 14 days, conditioned to the periodic evaluation of the nurse.

The occlusion has been cited in other studies as the main reason for the PICC removal. A research found this factor, followed by rupture and accidental displacement. Another study presented occlusion followed by complete thrombosis and infection, and a third study resulted in the following reasons for catheter removal: occlusion (24\%, $n$ $=8)$, infection $(24 \%, n=7)$, thrombosis $(18 \%, n=5)$ and migration $(18 \%, n=5)^{(5,10,12)}$.

It is important to highlight that not all cases of occlusion lead to the catheter removal. In another study, the lumen occlusion occurred in 26 (7.3\%) PICC. From these, 14 (53.8\%) PICC had their permeability successfully restored. In another study, 17 patients (5\%) had PICC occlusions, of which 16 were partial occlusions, mainly due to inadequate care with the catheter at home, and the permeability of all 16 patients catheters was restored. One patient was only showing total occlusion ${ }^{(5,11)}$.

Although in many cases the catheter occlusion does not culminate in its removal, this complication has been shown with great frequency in the literature. Other studies have shown occlusion and infection to be the most frequent complications in central venous catheters, with emphasis on PICC (5,10-12). In the present study, from the 141 catheters that had occlusion, 63 (44.7\%) were removed for causes related to the occlusion, and the other 78 (55.3\%) were associated with other factors as the cause of their removal.

It was observed a statistically significant association with the catheter's dwell time, with the use of cyclophosphamide, with the diagnosis of neuroblastoma, with bone metastasis and with the number of chemotherapy sessions.

Although this study has limitations in terms of proving the reason between these associations and the occlusion outcome, it was possible to identify the weights of these associations based on the calculation of the odds ratio, which showed significant values. Another limitation of the study was the choice of the scenario, based on the oncology care network. Although it is an important center in terms of the quality and quantity of care provided to the population, it is suggested for similar future studies, a multicentric approach, in order to cover the entire population. However, despite the fact that the scenario has skewed 
the frequency estimates of some types of tumors, there was no compromise of another result, as the analysis and objectives did not depend on the incidence of leukemias or other types of tumors.

The mean and median dwell time of the PICC with occlusion were significantly greater than the mean and median dwell time of the PICC without occlusion. A patient who uses cyclophosphamide is 2.6 times more likely to present occlusion in the PICC than a patient who does not use this medication. The chance of a catheter in a patient who has neuroblastoma to present occlusion is 7.2 times the chance of a catheter in a patient who does not have neuroblastoma to present occlusion. This same chance applies to cases of bone metastasis.

The mean and median number of PICC chemotherapy sessions with occlusion were significantly higher than the mean and median number of PICC chemotherapy sessions without occlusion.

Thus, the results showed that the clinical-pathological profile of pediatric patients in antineoplastic chemotherapy treatment interfered with the occurrence of PICC occlusions. However, the weights between the identified associations have not been previously reported in the literature, which leads to the need for further studies.

\section{a CONCLUSION}

The occlusion occurred in more than half of the cases and was one of the main reasons for PICC removal. There was a statistically significant association with the catheter dwell time, cyclophosphamide, neuroblastoma, bone metastasis and number of chemotherapy sessions. Knowing the associations related to the risk of PICC occlusion can guide nurses' decision-making in care management.

Data on the use of PICC in the investigated population are still limited. Complications are subjects of studies, but they are approached in general, which implies the need to study risk factors and ways to avoid and solve each complication.

\section{DEFERENCES}

1. Lima BC, Silva LF, Góes FGB, Ribeiro MTS, Alves LL. The therapeutic pathway of families of children with cancer: difficulties faced in this journey. Rev Gaúcha Enferm. 2018;39:e20180004. doi: https://doi. org/10.1590/1983-1447.2018.20180004

2. Steliarova-Foucher E, Colombet M, Ries LAG, Moreno F, Dolya A, Bray F, et al. International incidence of childhood cancer, 2001-10: a population-based registry study. Lancet Oncol. 2017;18(6):719-31. doi: https://doi.org/10.1016/ S1470-2045(17)30186-9
3. Lima AFC, Saba ABS, Bianchini SSB, Fernando T. Preventive risk analysis in the maintenance of patency of the peripherally inserted central catheter. Rev Esc Enferm USP. 2019;53:e03462. doi: https://doi.org/10.1590/ s1980-220x2018011803462

4. Oliveira $C G$, Rodas $A C D$. Postmarketing surveillance in Brazil: vascular catheters - an overview of notifications of adverse events and technical complaints. Ciênc Saúde Coletiva. 2017;22(10):3247-57. doi: https://doi. org/10.1590/1413-812320172210.17612017

5. Madabhavi I, Patel A, Sarkar M, Kataria P, Kadakol N, Anand A. A study of the use of peripherally inserted central catheters in cancer patients: A single-center experience. J Vasc Nurs. 2018;36(3):149-56. doi: https://doi.org/10.1016/j. jvn.2018.05.001

6. Machado LBL, Moura DA, Cunha LBC, Cunha KCS. Characteristic of catheters and of children with oncohematological disease. Cogitare Enferm. 2017;22(1):1-10. doi: https://doi.org/10.5380/ce.v22i1.48448

7. Chan RJ, Northfield S, Larsen E, Mihala G, Ullman A, Hancock P, et al. Central venous access device securement and dressing effectiveness for peripherally inserted central catheters in adult acute hospital patients: a pilot randomised controlled trial. Trials. 2017;18:458. doi: https://doi.org/10.1186/ s13063-017-2207-x

8. Hill J, Broadhurst D, Miller K, Cook C, Dumansky J, Friesen N, et al. Occlusion management guideline for Central Venous Access Devices (CVADs). Vasc Access. 2013 [cited 2019 Sep 8];7(Suppl 1):1-36. Available from: http://www. improvepicc.com/uploads/5/6/5/0/56503399/omg_2013_final_revised.pdf

9. Leandro TA, Silva VM, Lopes MVO, Guedes NG, Nunes MM, Sousa TM, et al. Impaired comfort in children and adolescents with cancer. Rev Bras Enferm. 2018;71(3):934-41. doi: https://doi.org/10.1590/0034-7167-2017-0050

10. Borretta L, MacDonald T, Digout C, Smith N, Fernandez CV, Kulkarni K. Peripherally inserted central catheters in pediatric oncology patients: a 15-year population-based review from Maritimes, Canada. J Pediatr Hematol Oncol. 2017;40(1):e55-e60. doi: https://doi.org/10.1097/MPH.0000000000000882

11. Rykov MY, Zaborovskij SV, Shvecov AN, Shukin WV. Peripherally inserted central catheters in the treatment of children with cancer: results of a multicenter study. I Vasc Access. 2018;19(4):378-81. doi: https://doi. org/10.1177/1129729818757970

12. Fadoo Z, Nisar MI, Ittikhar R, Ali S, Mushtaq N, Sayani R. Peripherally inserted central venous catheters in pediatric hematology/oncology patients in tertiary care setting: a developing country experience. I Pediatr Hematol Oncol. 2015;37(7):421-23. doi: https://doi.org/10.1097/MPH.0000000000000369

13. Antunes BP, Becker RG, Brunetto AT, Pavei $B S$, de-Farias $C B$, Rivero LFR, et al. Expression of neurotrophins and their receptors in primary osteosarcoma. Rev Col Bras Cir. 2019;46(2):e2094. doi: https://doi. org/10.1590/0100-6991e-20192094

14. Zouain-Figueiredo GP, Zandonade E, Amorim MHC, Figueiredo LZ, Binda LA. Perfil epidemiológico dos casos novos de câncer infanto-juvenil em hospital de referência no Espírito Santo, Brasil, de 1986 a 2010. Rev Bras Pesq Saúde. 2015;17(4):109-20. doi: https://doi.org/10.21722/rbps.v17i4.14337

15. Köksal, H, Müller E, Inderberg EM, Bruland 0, Wälchli S. Treating osteosarcoma with CAR T cells. Scand J Immunol. 2019;89(3):11-8. doi: https://doi. org/10.1111/sji.12741

16. Fermo VC, Lourençatto GN, Medeiros TS, Anders JC, Souza AlJ. Early diagnosis of child cancer: the journey taken by families. Esc Anna Nery. 2014 [cited 2019 Sep 10];18(1):54-9. Available from: https://www.scielo.br/scielo. php?pid=\$1414-81452014000100054\&script=sci_arttext\&tlng $=$ en 
17. Krein SL, Saint S, Trautner BW, Kuhn L, Colozzi J, Ratz D, et al. Patient-reported complications related to peripherally inserted central catheters: a multicentre prospective cohort study. BMJ Qual Saf. 2019;28(7):574-81. doi: https://doi. org/10.1136/bmjas-2018-008726

\section{- Acknowledgment:}

This present work was realized with the support of the Coordination for the Improvement of Higher Education Personnel (Coordenação de Aperfeiçoamento de Pessoal de Nível Superior - CAPES) - Funding Code 001.

\section{- Corresponding author:}

Marcelle Miranda da Silva

Email:marcellemsufrj@gmail.com
18. Cotogni P, Barbero C, Garrino C, Degiorgis C, Mussa B, De Francesco A, et al. Peripherally inserted central catheters in non-hospitalized cancer patients: 5-year results of a prospective study. Support Care Cancer. 2015;23(2):403-9. doi: https://doi.org/10.1007/s00520-014-2387-9

\section{Associate editor:}

Jéssica Machado Teles 